\title{
Malic Enzyme Activity in Adult and Newborn Rat Lung
}

\author{
RENEE E. FOX, KENNETH G. KINGWELL, AND J. TYSON TILDON \\ Departments of Pediatrics /R.E.F. K.G.K., J.T.T.J and Biological Chemistry /J.T.T.J. Liniversity of Maryland \\ School of Medicine, Baltimore, Maryland 21201
}

\begin{abstract}
Using a sensitive technique measuring ${ }^{14} \mathrm{CO}_{2}$ production from radiolabeled malate, we examined malic enzyme activity in both adult and newborn rat lung tissue and in $\mathrm{L} 2$ cells, a cell culture line of type II pneumocytes. Malic enzyme was present in both cytosolic and mitochondrial fractions. Time course experiments demonstrated a linear rate after the initial $10 \mathrm{~min}$, up to $30 \mathrm{~min}$. The optimal $\mathrm{pH}$ in the cytosolic fraction was 8.0 , whereas maximal mitochondrial malic enzyme activity occurred at pII 7.0. The mitochondrial fraction exhibited biphasic kinetics over the 200-fold range of concentrations examined. The high-affinity $\mathrm{Km}$ was $0.16 \mathrm{mmol}$ with $\mathrm{V}_{\max }$ of $7.11 \mathrm{nmol} / \mathrm{mg}$ protein/min. The low-affinity $\mathrm{Km}$ was 6.95 $\mathrm{mmol}$, with $\mathrm{V}_{\max }$ of $31.82 \mathrm{nmol} / \mathrm{mg}$ protein/min. In the cytosol there was a single $\mathrm{Km}$ of $0.30 \mathrm{mmol}$ and $V_{\max }$ of $5.95 \mathrm{nmol} / \mathrm{mg}$ protein/min. In paired experiments examining differences between 1-d-old and adult rat lung, significantly higher total and mitochondrial malic enzyme activity occurred in the newborn as compared with the adult. Malic enzyme activity was also present in the L2 cells. The finding of malic enzyme activity in the lung suggests that cytosolic malic enzyme may play a role in generating NADPH needed in the lung for fatty acid synthesis. These findings of developmental differences in malic enzyme activity suggest that alternate substrates such as anaplerotic amino acids may be used in the young animal as energy substrates by way of the tricarboxylic acid cycle. (Pediatr Res 35: 589-593, 1994)
\end{abstract}

The lung is the site of extensive fatty acid synthesis that is required for both the production of the phospholipids used in surfactant and neutral lipids used in the structural membranes of lung tissues (1). The high rate of fatty acid synthesis that occurs before birth and during the neonatal period is crucial for development of lung tissue and pulmonary function compatible with survival after birth in both human beings and other mammals (2).

Fatty acid synthesis requires NADPH as a cofactor, and it is generally accepted that NADPH is generated via the hexose monophosphate shunt. However, this cofactor is also produced in the reaction catalyzed by malic enzyme.

Malic enzyme (EC 1.1.1.40), which has been shown to be present in both cytosolic and mitochondrial fractions in most tissues (4-6) converts malate to pyruvate producing $\mathrm{CO}_{2}$ and generating NADPH as shown in the following formula:

$$
\text { Malate }+\mathrm{NADP}^{+} \rightarrow \text { Pyruvate }+\mathrm{CO}_{2}+\mathrm{NADPH}
$$

In addition to its role in providing NADPH, malic enzyme has

Received June 1. 1993; accepted December 13, 1993.

Correspondence: Renee E. Fox. M.D., Department of Pediatrics, N5W68. University of Maryland Hospital, 22 South Greene St., Baltimore, MD 21201. been reported by several groups (3-5) to play a pivotal role in the four-to-three carbon shunt or "malate oxidation shunt" (Fig. 1). For glutamine to be completely oxidized, some of the accumulating malate must be converted to pyruvate, and this step would require malic enzyme. Without the presence of malic enzyme, the oxidation of glutamine would not be complete because, in the subsequent step, two carbons are added from acetyl CoA, and two carbons are liberated in the form of $\mathrm{CO}_{2}$, with no net oxidation of the four carbons of malate. Through the malate oxidation shunt, malic enzyme produces a threecarbon moiety (pyruvate) that may be returned to the tricarboxylic acid cycle after it conversion to acetyl CoA in the mitochondria (Fig. 1). This step allows for the complete oxidation of any anaplerotic compound as an alternate energy source for glucose. The balanced stoichiometry is:

$$
\begin{gathered}
2 \text { glutamine }+\mathrm{NADP}^{+}+3 \mathrm{FAD}^{+}+\mathrm{GDP} \rightarrow \\
1 \text { ketoglutarate }+4 \mathrm{NH}_{3}+\mathrm{NADPH}+3 \mathrm{NADH} \\
+3 \mathrm{FADH}+5 \mathrm{CO}_{2}+\mathrm{GTP}
\end{gathered}
$$

where FAD is flavin adenine dinucleotide, GDP is guanosine diphosphate, FADH is the reduced form of flavin adenine dinucleotide, and GTP is guanosine triphosphate. For example, several studies have shown that glutamine can be used as an alternate energy substrate in both developing and mature brain tissue and other organs (4-7).

Recent results from our laboratory suggest that glutamine may be a key energy substrate in newborn rat lung (8). Therefore, we initiated studies to characterize malic enzyme in lung tissue because little is known about the subcellular localization and regulation of the enzyme in developing lung. Using a sensitive assay developed in our laboratory, we characterized malic enzyme activity in the lung including enzymatic kinetics and subcellular localization, as well as the effect of different malate concentrations and $\mathrm{pH}$. We also compared malic enzyme activity in newborn and adult rats. In addition, we examined enzyme activity in a cell culture line of type II pneumocytes.

\section{MATERIALS AND METHODS}

Materials. Biochemicals and reagents-malic acid, NADP, sucrose, Tris- $\mathrm{HCl}$, and potassium EDTA were purchased from Sigma Chemical Company (St. Louis, MO). The fluor used for liquid scintillation counting (Ready Solve EP) was purchased from Beckman Instruments, Inc. (Fullerton, CA). Solutions for the Pierce BCA microreagent protein assay were purchased from Pierce (Rockford, IL). All reagents and chemicals were of highest analytical grade, and reagent grade water was used to prepare all reagent solutions. The radioactive compound $\mathrm{L}-\left[\mathrm{U}-{ }^{14} \mathrm{C}\right]$ malic acid $(53 \mathrm{mCi} / \mathrm{mmol})$ was purchased from Amersham Corporation (Arlington Heights, IL). Culture dishes (Nunc) were purchased from Vangard International (Neptune, NJ). Culture media (minimum essential medium with Earle's salts and nonessential amino acids), antibiotic and antimycotic solution and fetal 


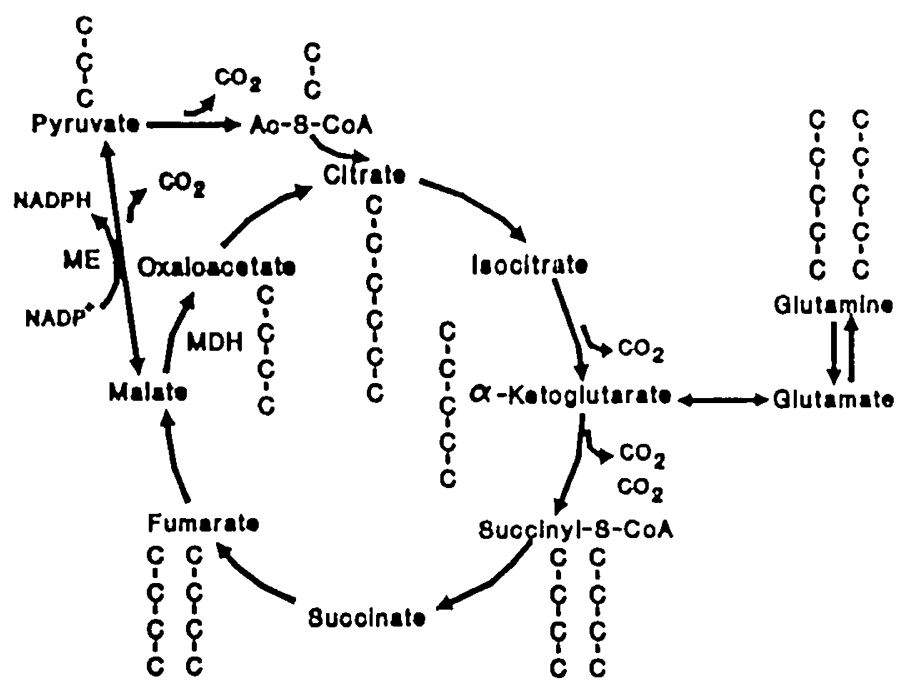

Fig. 1. The malate oxidation shunt. This pathway allows for the complete oxidation of glutamine and other anaplerotic substrates in the tricarboxylic acid cycle, allowing for the conversion of malate to pyruvate via malic enzyme (.$/ L E)$. In addition. NADPH is produced. $/ / D I I$, malate dehydrogenase: $1(-S-C o \cdot 1$ acetyl CoA.

bovine serum were obtained from Paragon Biotechnology, Inc. (Baltimore, MD).

Tissue Preparation. Adult rat lung tissue. The animal protocols in this study were approved by the University of Maryland School of Medicine Institutional Animal Care and Use Committee. Adult male Sprague-Dawley rats (Zivic Miller, Zelienople, PA) weighing between 225-250 $\mathrm{g}$ and fed standard rat chow ad libitum were given heparin for anticoagulation and ketamine for anesthesia. They were exsanguinated, and the heart and pulmonary circulation were perfused with $50 \mathrm{~mL}$ of solution II (140 $\mathrm{mM} \mathrm{NaCl}, 5 \mathrm{mM} \mathrm{KCl}, 2.5 \mathrm{mM} \mathrm{Na} \mathrm{HPO}_{4}, 10 \mathrm{mM}[\mathrm{N}-2-$ hydroxyethylpiperazine- $\mathrm{N}^{\prime}$-2-ethanesulfonic acid, $2.0 \mathrm{~m} \mathrm{M} \mathrm{CaCl}_{2}$ and $1.3 \mathrm{mM} \mathrm{MgSO}_{4}, \mathrm{pH} 7.4$ ) to remove blood from the lungs. The lungs were removed, and the large visible bronchi were excised. The lung tissue was placed in isolation medium (containing $0.25 \mathrm{mM}$ sucrose, $0.5 \mathrm{mM}$ EDTA, $100 \mathrm{mM}$ Tris, $\mathrm{pH}$ 7.4) and minced on ice. The tissue was homogenized by hand with 10 strokes of an ice-jacketed Tenbroeck homogenizer (Wheaton Science Products, Inc., Millville, NJ). The homogenate was centrifuged at $6000 \times g$ to remove cell debris. The supernatant was recentrifuged at $34000 \times g$ to separate cytosolic and mitochondrial fractions. The mitochondrial pellet was resuspended in isolation medium and sonicated for $10 \mathrm{~s}$ three times in a Branson Sonifier to disrupt the mitochondrial membrane.

The presence of microsomes in the cytosolic fraction had no effect on the level of malic enzyme activity. When the cytosolic fraction was further centrifuged at $488000 \times g$ for $20 \mathrm{~min}$ to remove the microsomes, the malic enzyme activity was the same as the activity of the cytosolic fraction prepared as described above (data not shown). The mitochondrial/cytosolic ratio of lactate dehydrogenase was 0.17 , which is consistent with lactate dehydrogenase being a predominately cytosolic enzyme. Succinate dehydrogenase, a predominately mitochondrial enzyme, had a mitochondrial/cytosolic ratio of 4.86 .

Newborn rat lung tissue. Lungs from 1-d-old rat pups were obtained after decapitation. The pups, weighing an average of 8 $\mathrm{g}$, had been kept with their dams and had been allowed to nurse freely. The dams were provided free access to standard rat chow and water. Lungs from two litters were combined to provide sufficient tissue. The tissue was minced and prepared as described above for the adult to obtain cytosolic and mitochondrial fractions.

L2 cells. L2 cells, cloned adult rat type II pneumocyte cells, were obtained from American Tissue Culture Collection (Rockville, MD). They were plated and cultured in minimum essential medium with $10 \%$ fetal bovine serum for 7-10 days until grown to confluence in $95 \%$ air, $5 \% \mathrm{CO}_{2}$ at $37^{\circ} \mathrm{C}$. The cells were washed twice with isolation media, scraped, pooled, and homogenized. The subcellular fractions were prepared as described above.

Measurement of Malic Enzyme Activity. Malic enzlme activity: Malic enzyme was assayed by measuring production of ${ }^{14} \mathrm{CO}_{2}$ from $\mathrm{L}-\left[\mathrm{U}-{ }^{14} \mathrm{C}\right]$ malate. The assay is an adaptation of the method outlined by Hsu and Lardy (9) with the exception that ${ }^{14} \mathrm{CO}_{2}$ production is measured rather than NADPH production. Preliminary experiments revealed that the assay was proportional to protein concentration and gave results comparable to the spectrophotometric method. However, the sensitivity of the assay was increased about 10-fold compared with the spectrophotometric method, allowing for the use of small amounts of cells per tissue.

For these experiments the reaction mixture contained $75 \mathrm{mM}$ Tris $\mathrm{HCl}, 4 \mathrm{mM}$ NADP, $5 \mathrm{mM} \mathrm{MnCl}$, and varying concentrations of malate. Samples were incubated in a shaking water bath at $37^{\circ} \mathrm{C}$. The reaction was started by the addition of the two subcellular fractions. Blanks with no tissue were run with each assay to correct for any nonenzymatic ${ }^{14} \mathrm{CO}_{2}$ release. At different times as described in the experimental protocol, the reaction was stopped with $0.3 \mathrm{~mL}$ of $10 \%(\mathrm{vol} / \mathrm{vol})$ trichloroacetic acid. The rate of $\mathrm{CO}_{2}$ production was measured by trapping the ${ }^{14} \mathrm{CO}_{2}$ in center wells containing methylbenzonium hydroxide. The center wells were transferred to vials, and scintillation fluid was added and counted in a liquid scintillation spectrometer.

Protein concentration. Protein concentration of the tissue samples was determined by the Pierce BCA protein assay microreagent system (10). Enzyme activity was expressed in $\mathrm{nmol} / \mathrm{mg}$ protein/min.

Statistical analysis. Each experiment was replicated at least three to four times. Kinetic parameters were determined with linear regression analysis. Data for the comparison of malic enzyme activity in adult and 1 -d-old rat lung tissue were tested for significance using a paired $t$ test.

\section{RESULTS}

The time course for malic enzyme activity as measured by ${ }^{14} \mathrm{CO}_{2}$ production is shown in Table 1 for both the cytosol and mitochondrial fractions. During this 30 -min time period, the rate was essentially linear from 15 to $30 \mathrm{~min}$, and we chose time periods on that part of the curve for our subsequent kinetic and $\mathrm{pH}$ studies. The activity was measured in the presence and absence of NADP. The activity in cytosolic fraction in the absence of NADP was only $13.7 \pm 4.0 \%$ (mean \pm SD) of the activity found when exogenous NADP was added. In contrast, in the absence of exogenous NADP, the mitochondrial fraction had approximately $50 \%$ the activity found when NADP was added to the reaction mixture $(50.3 \pm 6.5 \%$, mean $\pm S D)$,

Table 1. Effect of varying incubation time on ${ }^{14} \mathrm{CO}$ production (nmol/mg protein/min) at $2 \mathrm{mM} /$ malate concentration in both cytosolic and mitochondrial fractions of adult rat hung tissue, pII $7.4^{*}$

\begin{tabular}{|c|c|c|c|c|}
\hline \multirow[b]{2}{*}{$\begin{array}{l}\text { Time } \\
(\min )\end{array}$} & \multicolumn{2}{|c|}{ Cytosol } & \multicolumn{2}{|c|}{ Mitochondria } \\
\hline & $\begin{array}{l}\text { With } \\
\text { NADP }\end{array}$ & $\begin{array}{l}\text { Without } \\
\text { NADP }\end{array}$ & $\begin{array}{l}\text { With } \\
\text { NADP }\end{array}$ & $\begin{array}{l}\text { Without } \\
\text { NADP }\end{array}$ \\
\hline 5 & $2.16 \pm 0.23 \dagger$ & $0.45 \pm 0.05$ & $6.59 \pm 0.40$ & $5.84 \pm 1.43$ \\
\hline 10 & $2.48 \pm 0.88$ & $0.31 \pm 0.14$ & $5.78 \pm 1.92$ & $2.36 \pm 0.95$ \\
\hline 15 & $1.24 \pm 0.14$ & $0.22 \pm 0.05$ & $3.89 \pm 0.80$ & $1.76 \pm 0.49$ \\
\hline 20 & $1.72 \pm 0.26$ & $0.24 \pm 0.04$ & $4.73 \pm 0.85$ & $2.26 \pm 0.33$ \\
\hline 25 & $1.63 \pm 0.24$ & $0.23 \pm 0.05$ & $3.95 \pm 0.45$ & $2.06 \pm 0.28$ \\
\hline 30 & $1.92 \pm 0.54$ & $0.15 \pm 0.05$ & $4.12 \pm 1.28$ & $2.16 \pm 0.65$ \\
\hline
\end{tabular}

* Each time point was repeated three to five times and performed in quadruplicate during each experiment.

$\dagger$ Values are mean \pm SEM. 
suggesting significant levels of endogenous NADP in the mitochondrial fraction.

To further characterize the enzyme in lung tissue, we examined the effects of $\mathrm{pH}$ on malic enzyme activity in adult rat lung tissue (Fig. 2). Varying the $\mathrm{pH}$ of the reactions had a differential effect on malic enzyme activity in the two subcellular fractions. When measured at increasing $\mathrm{pH}$ values, the cytosolic activity increased from a mean of $1.59 \mathrm{nmol} / \mathrm{mg}$ protein $/ \mathrm{min}$ at $\mathrm{pH} 6.5$ to a maximum of $3.96 \mathrm{nmol} / \mathrm{mg}$ protein $/ \mathrm{min}$ at $\mathrm{pH} 8$. The activity was about half that value at $\mathrm{pH} 9(1.86 \mathrm{nmol} / \mathrm{mg}$ protein $/ \mathrm{min})$. In contrast, the enzyme activity in the mitochondria was essentially the same from $\mathrm{pH} 7$ to $8(3.07 \mathrm{nmol} / \mathrm{mg}$ protein $/ \mathrm{min}$ at $\mathrm{pH} 7$ and $2.52 \mathrm{nmol} / \mathrm{mg}$ protein $/ \mathrm{min}$ at $\mathrm{pH} 8$ ) but decreased to essentially zero at $\mathrm{pH} 8.5$ and 9.

The effect of varying the initial substrate concentration on the enzyme activity in adult lung tissues in both cytosolic and mitochondrial fractions is shown in Figure 3. In the mitochondrial fraction, the enzymatic activity did not follow simple Michaelis-Menten kinetics as revealed by the Eadie-Hofstee plot (Fig. 3.A) but was biphasic. This fraction showed an increase of activity throughout the 200 -fold range of malate concentration. The Eadie-Hofstee plot shown in Figure 3.1 is best represented by two linear segments. Analysis of these data yielded a highaffinity $\mathrm{Km}$ of $0.16 \mathrm{mmol}, \mathrm{V}_{\max }=7.11 \mathrm{nmol} / \mathrm{mg}$ protein $/ \mathrm{min}$, and a low-affinity $\mathrm{Km}$ of $6.95 \mathrm{mmol}, \mathrm{V}_{\max }=31.82 \mathrm{nmol} / \mathrm{mg}$ protein $/ \mathrm{min}$.

In contrast to the mitochondria, the cytosolic enzymatic activity followed simple Michaelis-Menten kinetics, with a single $\mathrm{Km}$ of $0.30 \mathrm{mmol}, \mathrm{V}_{\max }$ of $5.95 \mathrm{nmol} / \mathrm{mg}$ protein $/ \mathrm{min}$, as shown in Figure $3 B$.

In paired experiments examining differences in enzyme activity between adult and 1-d-old rat lung tissue, malic enzyme was present in both mitochondrial and cytosolic fractions at both ages (Fig. 4). The activity was higher in the newborn, with a total mean activity of $11.16 \mathrm{nmol} / \mathrm{mg}$ protein $/ \mathrm{min}$ as compared with mean activity in the adult lung of $8.07 \mathrm{nmol} / \mathrm{mg}$ protein $/ \mathrm{min}(p)$ $<0.5$ paired $t$ test). The mitochondrial activity in the newborn was $8.47 \mathrm{nmol} / \mathrm{mg}$ protein $/ \mathrm{min}$, which was more than twice the mitochondrial activity in the adult $(3.92 \mathrm{nmol} / \mathrm{mg}$ protein $/ \mathrm{min})$ $(p<0.05$, paired $t$ test $)$. In the adult cytosolic fraction the mean activity was $4.15 \mathrm{nmol} / \mathrm{mg}$ protein $/ \mathrm{min}$, whereas in the newborn

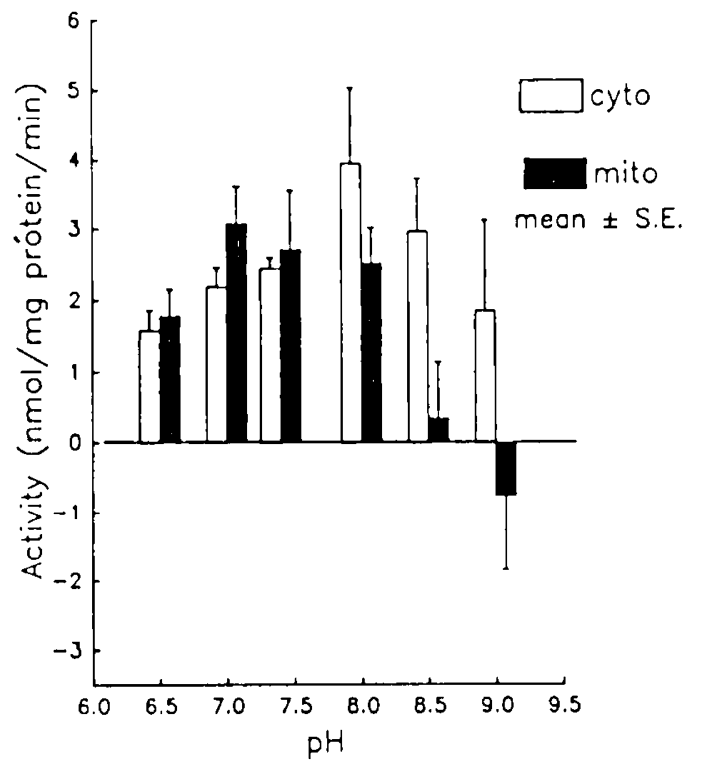

Fig. 2. The effect of pH of malic enzyme activity in adult rat lung tissue in both cytosolic (open bars) and mitochondrial (solid hars) fractions. The rate of ${ }^{14} \mathrm{CO}_{2}$ production was measured at $\mathrm{pH} 6.5,7.0$. 7.4. 8.0.8.5, and 9.0 for $15-\mathrm{min}$ incubation in the presence of $5 \mathrm{mM}$ malate at $37^{\circ} \mathrm{C}$ as described in Materials and Methods. These results are mean \pm SEM from four experiments in which the activity at each pH value was measured in quadruplicate.
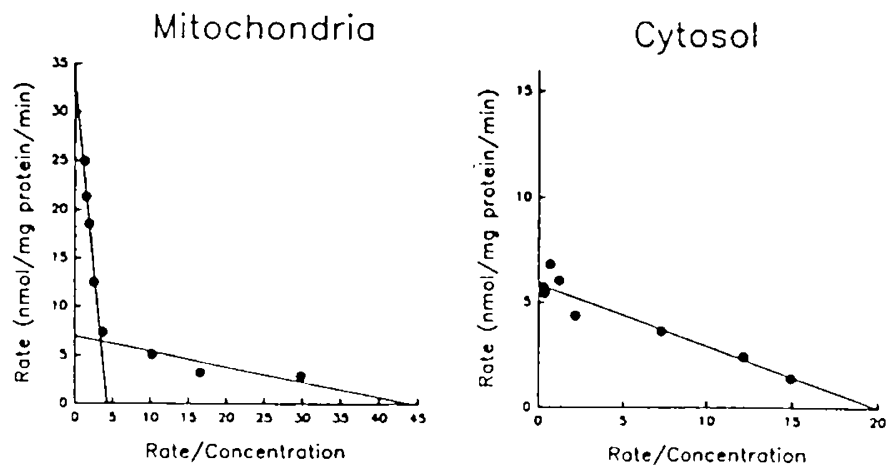

Fig. 3. Eadie-Hofstee plots of the effect of varying the initial substrate concentration on the malic enzyme activity in the mitochondria $(.1)$ and cytosol $(B)$. Rate of ${ }^{14} \mathrm{CO}_{2}$ production was measured at malate concentrations of $0.1,0.2,0.5,2.0,5,10,15$, and $20 \mathrm{mM}$ during a $30 \cdot \mathrm{min}$ incubation at $37^{\circ} \mathrm{C}, \mathrm{pH} 7.4$. Experiments were repeated three to six times at each concentration. Each concentration was done in quadruplicate during each experiment. The points represented are the mean values. $\mu$, The mitochondrial fraction kinetics are best represented by two linear segments of the Eadic-Hofstee plot: a high-aflinity $(0.1-2 \mathrm{mM})$ segment with a calculated $\mathrm{Km}$ of $0.16 \mathrm{mM}$ and $V_{\text {max }}$ of $7.11 \mathrm{nmol} / \mathrm{mg}$ protein/ $\min \left(r^{2}=0.79\right)$ and a low-affinity $(2-20 \mathrm{mM})$ segment with a calculated $\mathrm{Km}$ of $6.95, \mathrm{~V}_{\max }$ of $31.82 \mathrm{nmol} / \mathrm{mg}$ protein $/ \mathrm{min}\left(r^{2}=0.96\right)$. B. Kinetics in the cytosol where a single linear regression yielded a $\mathrm{Km}$ of $0.30 \mathrm{mM}$ and $\mathrm{V}_{\text {max }}$ of $5.95 \mathrm{nmol} / \mathrm{mg}$ protein $/ \mathrm{min}\left(r^{2}=0.90\right)$ throughout the concentration range examined.

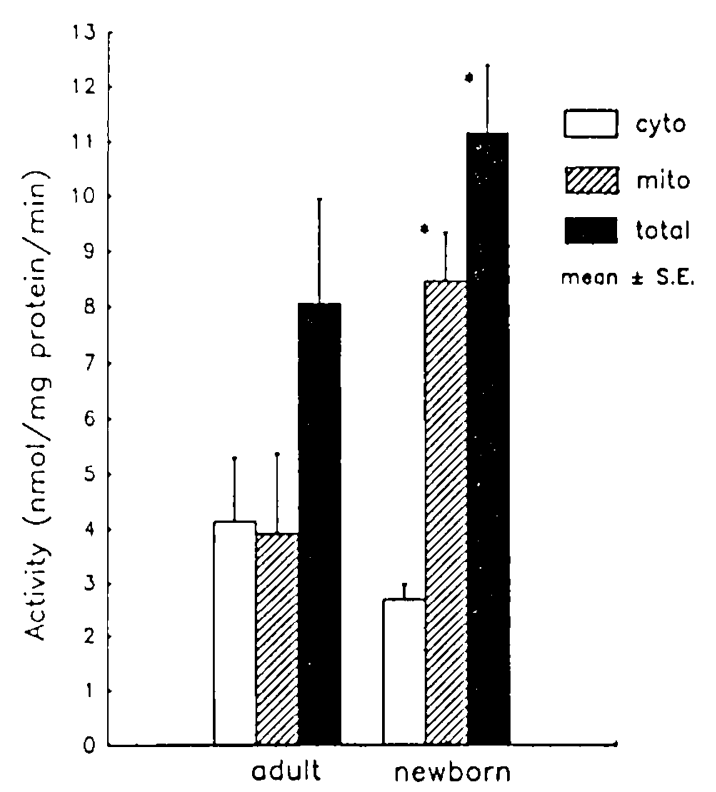

Fig. 4. Malic enzyme activity in adult and newborn rat lung tissue. In paired experiments examining differences in enzyme activity between adult and 1-d-old rat lung tissue. malic enzyme was present in both mitochondrial and cytosol fractions at both ages. There was significantly higher total malic enzyme activity (solid hars) $(*, p<0.05)$ and significantly higher mitochondrial activity (hatched hars) in the newborn $\left(^{*}, p\right.$ $<0.05$ ) compared with the adult. This activity results in a shift of the ratio of mitochondrial to cytosolic activity from about 2.5 in the newborn rat lung to a ratio of about 1 in the adult. The cytosolic activity is shown in the open hars. Experimental conditions: $\mathrm{pH} 7.4,37^{\circ} \mathrm{C}, 15-\mathrm{min}$ incubation. $5 \mathrm{mM}$ malate. Enzyme activity is expressed as nmol ${ }^{14} \mathrm{CO}_{2}$ produced $/ \mathrm{mg}$ protein $/ \mathrm{min}$. Data shown as mean \pm SEM, $n=4$. Within experiments, points were repeated in quadruplicate.

the mean activity was $2.69 \mathrm{nmol} / \mathrm{mg}$ protein/min. This activity results in a shift of the ratio of mitochondrial to cytosolic activity from about 2.5 in the newborn rat lung to a ratio of about 1 in the adult. 
To further characterize this enzyme in the lung, we assayed the malic enzyme activity in cultured L2 cells. The cytosolic activity was $4.07 \pm 2.47 \mathrm{nmol} / \mathrm{mg}$ protein $/ \mathrm{min}$ (mean $\pm \mathrm{SEM}$ ), and the mitochondrial activity was $1.98 \pm 1.21 \mathrm{nmol} / \mathrm{mg}$ protein $/ \mathrm{min}$ (mean $\pm \mathrm{SEM}$ ) at $5 \mathrm{mM}$ malate concentration and $\mathrm{pH}$ 7.4. The resultant ratio of mitochondrial to cytosolic activity was about 0.50 in these cells.

\section{DISCUSSION}

Using a sensitive technique developed in our laboratory, we were able to detect malic enzyme activity in both adult and newborn rat lung tissue and L2 cells, a cell culture line of type II pneumocytes. Previous attempts by other investigators to determine the presence of malic enzyme in lung tissue have produced varied results. Scholz and Rhoades (11) and Das and Ganguly (12) failed to detect malic enzyme activity in lung cytosol. Furthermore, these workers were not able to induce malic enzyme activity in the lungs of diabetic and hypophysectomized rats treated with triiodothyronine (12). Dozin et al. (13) reported malic enzyme activity as determined by rate of NADPH production in lung tissue. In addition, they found that malic enzyme mRNA was expressed in the lung. In their study (13), no change occurred in malic enzyme activity or amount of mRNA expressed after treatment with triiodothyronine in the lung, in contrast to the effect in the heart, liver, and kidney.

Batenburg and Whitsett (14) also measured malic enzyme mRNA and found no effect of nutritional status on the expression of malic enzyme mRNA in the lung. This finding was unlike the results in the liver, where starvation caused a small decrease and where refeeding produced a significant increase in mRNA. Although the changes in the expression of lung malic enzyme mRNA during starvation were not statistically significant, the results were suggestive of a decrease. This group did not measure enzyme activity, so if posttranscriptional changes in enzyme regulation had occurred, they would not have detected them.

In this report, we demonstrated that cytosolic and mitochondrial malic enzyme have several different properties. The mitochondrial fraction demonstrated biphasic kinetics within the 200fold range of concentrations examined. However, in the cytosol, there was a single $\mathrm{Km}$ and $\mathrm{V}_{\max }$. Although malic enzyme has been characterized in other tissues, including the brain and its cell types, astrocytes and synaptosomes $(15,16)$, no previous characterizations of the enzyme kinetics of malic enzyme in the lung have been made.

The enzymes in the two subcellular localizations also showed ditferences with respect to $\mathrm{pH}$. The cytosolic enzyme demonstrated activity throughout the range of $\mathrm{pH}$ examined. The mitochondrial enzyme activity was more affected by $\mathrm{pH}$, having the highest activity at pH values between 6 and 8. Our findings would argue that indeed two different enzymes are present in the cytosol and mitochondrial of the rat lung. This finding is in agreement with previous descriptions by Dozin et al. (13) of two different malic enzyme mRNAs in this tissue. This group has characterized the malic enzyme gene, and analysis of the $3^{\prime}$ end demonstrated that use of alternate polyadenylation signals in exon 14 resulted in two mRNA with $3^{\prime}$ untranslated regions of 345 and 1345 nucleotides, respectively (17).

Our results reveal important developmental differences in the activity of malic enzyme when the newborn rat lung was compared with adult lung. Significantly higher total malic enzyme activity, as well significantly higher mitochondrial activity, occurred in the newborn. We did not control for dietary differences between the newborn and adult, which may have a role in the differences seen between newborn and adult malic enzyme activity. However, the higher rate of malic enzyme activity in the newborn suggests that alternate substrates such as anaplerotic amino acids (e.g. glutamine) may be used to a greater extent in the young animal as energy substrates for cellular metabolism by way of the tricarboxylic acid cycle.

This concept is supported by our recent report of the higher use of glutamine when compared with glucose as an energy substrate by fetal rat lung fibroblasts (8). Because glutamine is the amino acid present in highest concentration in the serum (18), increased mitochondrial malic enzyme activity may play a key regulatory role to provide substrates for energy metabolism in the developing lung, as we have proposed (8). This mechanism may be particularly important in the newborn period when serum glucose levels may be low (19). Notably, glutamine has been shown to be a major energy substrate for several tissues, including brain (4) and intestine (20).

The role of ketone bodies in the neonatal period has been reviewed by Patterson and Rhodes (21). Ych (22) and Sheehan and $Y \mathrm{ch}(23)$ have explored the incorporation of these substrates into lung phospholipids, showing that these substrates are important precursors for surfactant lipids in the nconatal animal. Furthermore, the enzymes involved in lipogenesis from ketone bodies are elevated in the newborn period in the lung (22), which correlates with our results of an elevated malic enzyme activity in the newborn lung. The involvement of multiple substrates for lipogenesis in the lung suggests the possible need for multiple sources of NADPH.

Yeh (24) demonstrated that type Il cells isolated from newborn and adult rats incorporated ${ }^{14} \mathrm{C}$-labeled acetoacetate into phosphatidylcholine, the major component of surfactant phospholipids. In the newborn rat, acetoacetate was used preferentially compared with glucose for the production of phosphatidylcholine. This description agrees with our findings in the L2 cells, where the ratio of cytosolic to mitochondrial malic enzyme activity showed a predominance of activity in the cytosol. This is the subcellular localization where activity would be expected if malic enzyme were used to generate NADPH for fatty acid synthesis used in the generation of surfactant phospholipids in the type II pneumocyte.

Indeed, the contribution malic enzyme makes to fatty acid synthesis can be estimated. In the adult, the cytoplasmic rate was approximately $4 \mathrm{nmol} / \mathrm{mg}$ protein $/ \mathrm{min}$. One mole of NADPH is produced for each mole of $\mathrm{CO}_{2}$ produced. Fatty acid synthesis proceding from acetyl $\mathrm{CoA}$ to palmitate requires $14 \mathrm{nmol}$ NADPH for each nanomole of palmitate produced. In adult rat lung slices, Maniscalco et al. (25) determined the rate of fatty acid synthesis by measuring ${ }^{3} \mathrm{H}$ incorporation from ${ }^{3} \mathrm{H}_{2} \mathrm{O}$ into total saponifiable fatty acids to be $0.28 \mathrm{nmol} / \mathrm{mg}$ protein $/ \mathrm{min}$. The NADPH required for this rate of fatty acid synthesis would be $3.92 \mathrm{nmol} / \mathrm{mg}$ protein $/ \mathrm{min}$. This finding would suggest that malic enzyme is capable of producing much of the NADPH necessary for fatty acid synthesis.

In summary, we have determined that malic enzyme is indeed present in both mitochondrial and cytosolic fractions of the rat lung. The kinetics of the enzyme in the two subcellular fractions were different, as was the behavior of the two isoenzymes at varying $\mathrm{pH}$ values. A significant increase occurred in both total malic enzyme activity and in the amount of malic enzyme present in the mitochondria in the newborn rat lung as compared with the adult, suggesting an important developmental role for the use of alternate substrates for energy metabolism in the lung.

\section{REFERENCES}

1. Rooney SA 1985 The surfactant system and lung phospholipid biochemistry. Am Rev Respir Dis 131:439-460

2. Patterson CE, Davis KS, Beckman DE, Rhoades RA 1986 Fatty acid synthesis in the fetal lung: relationship to surfactant lipids. Biochim Biophys Acta $878: 110-126$

3. Zielke HR, Ozand PT, Tildon JT, Sevadalian DA, Cornblath M 1978 Reciprocal regulation of glucose and glutamine utilization by cultured human diploid fibroblasts. J Cell Physiol 95:41-48

4. Tildon JT, Zielke HR 1988 Glutamine: an energy source for mammalian tissues. In: Kvamme E (ed) Glutamine and Glutamate in Mammals. CRC Press, New York, pp 167-182

5. McKenna MC, Tildon JT, Couto R, Stevenson JH, Caprio FJ 1990) The 
metabolism of malate by cultured rat brain astrocytes. Neurochem Res 15:1211-1220

6. Roeder LM, Tildon JT, Holman DC 1984 Competition among oxidizable substrates in brains of young and adult rats: dissociated cells. Biochem $\mathbf{J}$ 219:131-135

7. Roeder LM, Tildon JT, Stevenson JH 1984 Competition among oxidizable substrates in brains of young and adult rats: whole homogenates. Biochem J 219:125-130

8. Fox RE, Kingwell KG, Tildon JT 1993 The role of glutamine as an energy source in the developing lung. Pediatr Res 33:326A(abstr)

9. Hsu RY, Lardy HA 1969 Malic enzyme. In: Colowick SP, Kaplan NO. Lowenstein JM (eds) Methods in Enzymology, Vol. 12. Academic Press, New York. pp 230-235

10. Smith PK, Krohn RI, Hermanson GT, Mallia AK, Gartner FH, Provenzano MD, Fujimoto EK, Gocke NM, Olson BJ, Klenk DC 1985 Measurement of protein using bicinchonic acid. Anal Biochem 150:76-85

11. Scholz RW, Rhoades RA 1971 Lipid metabolism by rat lung in vivo. Biochem J 124:257-264

12. Das DK, Ganguly M 1982 Mechanism of the control of pulmonary and hepatic fatty acid synthesis by the thyroid hormones. Arch Biochem Biophys 218:142-155

13. Dozin B, Magnuson MA, Nikodem VM 1985 Tissue-specific regulation of two functional malic enzyme mRNAs by triiodothyronine. Biochemistry $24: 5581-5586$

14. Batenburg JJ, Whitsett JA 1989 Levels of mRNAs coding for lipogenic enzymes in rat lung upon fasting and refeeding and during perinatal development. Biochim Biophys Acta 1006:329-334

15. McKenna MC, Tildon JT, Stevenson JH, Couto R, Kingwell KG, 1992 Activity of malic enzyme in cultured rat brain astrocytes and synaptosomes. FASEB J 6:A1501 (abstr)

16. McKenna MC, Tildon JT. Stevenson JH, Kingwell KG 1993 Regulation of astrocyte malic enzyme by metabolites. Am Soc Neurochem 24:A54(abstr)

17. Morioka H, Magnuson MA, Mitsuhashi T, Song M-KH, Rall JE, Nikodem VM 1989 Structural characterization of the rat malic enzyme gene. Proc Natl Acad Sci USA 86:4912-4916

18. Smith RJ 1990 Glutamine metabolism and its physiologic importance. J Parenter Enteral Nutr 14(suppl):40S-44S

19. Srinivasan G, Pildes RS, Cattamanchi G. Voora S, Lilien LD 1986 Plasma glucose values in normal neonates: a new look. J Pediatr 109:114-117

20. Souba WW, Herskowitz K. Salloum RM, Chen MK, Austgen TR 1990 Gut glutamine metabolism. J Parenter Enteral Nutr 14(suppl):45S-50S

21. Patterson CE, Rhoades RA 1989 Substrate utilization in the perinatal lung. Am J Physiol 275:L310-L330

22. Yeh YY 1982 Biosynthesis of lung lipids from acetoacetate and glucose in the developing rat in vivo. Int J Biochem 14:81-86

23. Sheehan PM, Yeh YY 1985 Pulmonary surfactant lipid synthesis from ketone bodies, lactate and glucose in newborn rats. Lipids 20:835-841

24. Yeh YY 199: Substrate utilization for phosphatidylcholine synthesis by type
. II pneumocytes of neonatal rats. Pediatr Res 30:55-61

25. Maniscalco WM. Finkelstein JN, Parkhurst AB 1982 De novo fatty acid synthesis in developing rat lung. Biochim Biophys Acta 11:49-58 